Summer 2010

\title{
Seeking Civilian Control: Rule of Law, Democracy, and Civil- Military Relations in Zimbabwe
}

Jeremiah I. Williamson

Indiana University Maurer School of Law

Follow this and additional works at: https://www.repository.law.indiana.edu/ijgls

Part of the Comparative and Foreign Law Commons, International Law Commons, Law and Politics Commons, and the Military, War, and Peace Commons

\section{Recommended Citation}

Williamson, Jeremiah I. (2010) "Seeking Civilian Control: Rule of Law, Democracy, and Civil-Military Relations in Zimbabwe," Indiana Journal of Global Legal Studies: Vol. 17 : Iss. 2 , Article 12.

Available at: https://www.repository.law.indiana.edu/ijgls/vol17/iss2/12

This Note is brought to you for free and open access by the Law School Journals at Digital Repository @ Maurer Law. It has been accepted for inclusion in Indiana Journal of Global Legal Studies by an authorized editor of Digital Repository@Maurer Law. For more information, please contactrvaughan@indiana.edu.

\section{$\Psi$}

JEROME HALL LAW LIBRARY

INDIANa UNIVERSITY

Maurer School of Law
Bloomington 


\title{
Seeking Civilian Control: Rule of Law, Democracy, and Civil-Military Relations in Zimbabwe
}

\author{
JEREMIAH I. WILLIAMSON*
}

\begin{abstract}
Rule of law and democratic reform projects often concern lofty questions of constitutional law. But in many countries desperate for reform, deeply entrenched social and political problems present preconditions to any discussion of constitutional reforms aimed at democracy and the rule of law. Zimbabwe is one such nation, which like many others faces the problem of military intervention into domestic politics. This Note examines structural and historical aspects of Zimbabwe's military problem and utilizes the theory of objective civilian control to demonstrate the plausibility of meaningful reforms. In so doing, this Note provides a demonstrative model for reforming civilmilitary relations in rule of law and democratic reform projects the world over.
\end{abstract}

\section{INTRODUCTION}

Democracy and rule of law reform projects are underway across the globe. In seeking change, reformers often contemplate such questions as the nature of the executive branch, ${ }^{1}$ the blueprint of the electoral

* Editor-in-Chief, Indiana Journal of Global Legal Studies; J.D. Candidate, 2010, Indiana University Maurer School of Law; B.A., 2006, University of California, Santa Cruz. I would like to thank David Williams and my classmates in the constitutional design research seminar for helpful comments on an earlier draft of this paper.

1. Compare Juan J. Linz, The Perils of Presidentialism, in The Global Resurgence OF DEMOCRACY 124 (Larry Diamond \& Marc F. Plattner eds., 2d ed. 1996) (arguing that parliamentary systems are more conducive to stable democracy than are presidential systems), with Donald L. Horowitz, Comparing Democratic Systems, in THE GLOBAL RESURGENCE OF DEMOCRACY, supra, at 143 (arguing that parliaments are subject to the same criticisms that Linz directs at presidents).

Indiana Journal of Global Legal Studies Vol. 17 \#2 (Summer 2010)

(C) Indiana University Maurer School of Law

DOI: $10.2979 /$ GLS.2010.17.2.389 
system, ${ }^{2}$ the authority of the judiciary, ${ }^{3}$ and the appropriateness of federalism. ${ }^{4}$ Yet these lofty legal ideas are often predicated on assumptions about the preparedness of a society to receive them. Sometimes countries face deep political and social problems that cannot be addressed by legal provisions alone, but that must nevertheless be resolved before democracy and the rule of law can take hold.

Zimbabwe is one such country. The African nation is home to more than eleven million people ${ }^{5}$ who have endured for three decades the horrors that follow from unstable civil-military relations. Time and again the General-turned-President Robert Mugabe has called upon the brute power of the armed forces to pursue political ends, the costs of which are best measured in terms of human rights abuses and criminal atrocities. Since Mugabe's style of military rule is all that Zimbabwe knows from its short democratic experience, it is hard to be optimistic about the prospects of constituting democracy and the rule of law in the troubled former British colony.

The story of Zimbabwe reminds us that "the most dangerous thing that democrats can do is to take the military for granted, or to assume that the problem of civil-military relations will eventually take care of itself." ${ }^{6}$ Recognizing this danger, the purpose of this Note is to show that hope is not lost for Zimbabwe. Pragmatic political and legal reforms can stabilize civil-military relations, bringing Zimbabwe one tremendous step closer to a democratic society ruled by law, not men.

The discussion begins by explaining Zimbabwe's complex politicalmilitary history, beginning with an overview of Zimbabwean military institutions, then summarizing three decades of military abuse. The historical discussion of civil-military relations in Zimbabwe closes with a description of the class of military elites ruling the nation today. With an understanding of the complex history and present day arrangement of civil-military relations in Zimbabwe, the limited but informative scholarship on civil-military relations is described. Using the late Samuel P. Huntington's theory of objective civilian control as a guide, legal, political, and institutional reforms are proposed with the goal of providing for civil-military relations that will allow democracy and the

2. See, e.g., AREND LiJPharT, PATTERnS OF DEMOCRACY: Government FormS AND PERFORMANCES IN THIRTY-SIX COUNTRIES 143-70 (1999).

3. See generally JoHN H. GARVEY ET AL., MODERN CONSTITUTIONAL THEORY 195-258 (5th ed. 2004).

4. See, e.g., Donald L. Horowitz, ETHNiC Groups IN Conflict 601-28 (2d. ed. 2000).

5. CENTRAL INTELLIGENCE AgENCY, THE WORLD FACTBOOK, available at https:/www.cia.gov/ibrary/publications/the-world-factbook/ (2010) (select Zimbabwe, then select "People") (last visited Mar. 14, 2010).

6. Larry Diamond \& Marc F. Plattner, Introduction to CIVIL-MnITARY RELATIONS AND DEMOCRACY, at xxxiv (Larry Diamond \& Marc F. Plattner eds., 1996). 
rule of law to take hold. The analysis illustrates the breadth of reforms that can be implemented to improve civil-military relations and, in this way, serves as a demonstrative model for developing objective civilian control in other troubled nations pursuing democracy and the rule of law.

\section{ZIMBABWEAN MILITARY INSTITUTIONS}

The Zimbabwe African National Liberation Army (ZANLA) and the Zimbabwe Independence People's Revolutionary Army (ZIPRA) began waging guerilla war against the British colonial Rhodesian government in the 1960s. ${ }^{7}$ From the Lancaster House Agreement declaring Zimbabwe's independence, the Zimbabwe National Army (ZNA) emerged as an integration of the members of the three warring parties: the Rhodesian Security Forces, ZANLA, and ZIPRA. ${ }^{8}$ Outside this integration process, the newly formed government also created by Act of Parliament the now infamous Fifth and Sixth Brigades. ${ }^{9}$ The initial forces totaled approximately 65,000 soldiers, ${ }^{10}$ at least two-thirds of which received basic training. ${ }^{11}$ Institutionally modeled after the British Army, ${ }^{12}$ and aided by a British Military Assistance and Training Team, the ZNA was widely viewed as an integrative success. ${ }^{13}$

The ZNA is the primary military unit within the Zimbabwe Defence Forces (ZDF), which include the Air Force of Zimbabwe (AFZ). ${ }^{14}$ The President appoints the commander of the ZDF, "who is the equivalent to the chairman of the Joint Chiefs of Staff."15 Below the commander of the $\mathrm{ZDF}$ are the commanders of the ZNA and $\mathrm{AFZ},{ }^{16}$ also appointed by the President. ${ }^{17}$ Within the ZDF are several elite groups, including the Paragroup, Presidential Guards, and the Special Air Service. ${ }^{18}$ For these

7. Eric T. Young, N'angasy Varoyi, and Midzimu: The Institutionalization of Traditional Beliefs in the Zimbabwe National Army, 24 ARMED FoRCES \& SOC'Y 245, 245 (1998).

8. Id.

9. Id. at 246 .

10. Id. at 245 .

11. Eric T. Young, Chefs and Worried Soldiers: Authority and Power in the Zimbabwe National Army, 24 ARMED FORCES \& SOC'Y 133, 134 (1997).

12. Id.

13. Id.

14. Reginald Matchaba-Hove, HIV/AIDS in the Zimbabwe Defence Force: A Civil Society Perspective, in THE ENEMY Within: Southern AFriCAN MILITARIES' QuarTerCENTURY BATTLE WITH HIV AND AIDS 157, 170 (Martin Rupiya ed., 2006).

15. Id.

16. Id.

17. See discussion infra Part IV.A.1.

18. Young, supra note 7 , at 246. 
elites of the Zimbabwean military, "training standards tend to be higher, entrance more selective, and equipment and facilities of higher quality than in the infantry brigades." 19 Other Zimbabwean security bodies include the Zimbabwe Republic Police, Zimbabwe Prisons Service, and the Central Intelligence Organisation. ${ }^{20}$

\section{A HISTORY OF ABUSE}

Zimbabwe's independence came only after a hard fought revolution. Revolutionary armies aspired to politics, operating on "the ideology that political power comes from the barrel of the gun."21 In the words of one general in the Zimbabwe Independence People's Army (ZIPA), "ZIPA is a unique and revolutionary army in the sense that it has a strategic role of transforming itself into a political movement." ${ }^{23}$ This idea of transforming revolutionary armies into political movements is the historical root of countless of Zimbabwe's atrocities of political violence. As one observer would note a decade later, there exists "a duality in the Zimbabwe Defense Forces, where 'professionalism is becoming the armed forces' public image and politicization the concealed reality."24

\section{A. Forcing ZAPU into Submission}

Following independence, politics remained divided in Zimbabwe. As the general-turned-political leader of ZANU-PF, Robert Mugabe unleashed a campaign of political terror to force the opposition ZAPU party to surrender its prerogatives to ZANU-PF. Mugabe's victims were dissidents in Matabeleland, where minority Nedebele speakers were concentrated and where ZAPU's guerilla army-ZIPRA-had operated in the 1970 s.

In response to the perceived threat of unsettled ex-ZIPRA guerillas, Mugabe personally sponsored the deployment of "the North Koreantrained Fifth Brigade, an elite and singularly brutal corps of ZANU liberation fighters. Their tactics-including torture, forced starvation,

19. Id.

20. Matchaba-Hove, supra note 14.

21. Knox Chitiyo \& Martin Rupiya, Tracking Zimbabwe's Political History: The Zimbabwe Defence Force from 1980-2005, in EvoluTIONS \& REVOLUTIONS 331, 350 (Martin Rupiya ed., 2005).

22. The Zimbabwe Independence People's Army (ZIPA) later became known as the Zimbabwe Independence People's Revolutionary Army (ZIPRA).

23. Mozambican Information Agency, The Zimbabwe People's Army: An Interview with Dzinashe Machingura, 7 ISSUE: J. OPINION at 15, 15 (1977).

24. Young, supra note 11. 
and the refusal to permit the burial of those summarily executedechoed and then exceeded the unspeakable atrocities committed on both sides of the anti-colonial war that had, in theory, just ended."25 Similar atrocities were committed in other districts. ${ }^{26}$ By the time ZAPU finally conceded to Mugabe's demands, as many as 8,000 people had been killed. ${ }^{27}$

These early years of political violence in Zimbabwe would set the tone for years to come. In three decades under Mugabe's guidance, "ZANU-PF has persistently threatened its political opponents with violence, intimidation and even murder."28 His "government has systematically targeted the judiciary, the independent media, opposition activists, white Zimbabweans and anyone else accused of betraying the goals of the liberation war."29

\section{B. Land Raiders}

Civil-military relations took a different form in Zimbabwe during the 1990s. With the former opposition ZAPU party now wholly subsumed within ZANU-PF, Mugabe shifted attention to a new enemy. Against urgings from abroad, Mugabe implemented his controversial land reformation plan. Easily painted as associates of colonial rule, white Zimbabwean farmers stood no chance at opposing Mugabe's controversial land reforms. Mugabe unleashed a mob of independence war veterans who "attacked and raped farm workers, burned their homes, and forced them to attend political education rallies." ${ }^{30}$ The High Court ordered the police commissioner, himself an ex-combatant, to remove the veterans from the farms. He refused, claiming it was a political problem and that the police lacked resources. ${ }^{31}$

\section{Electoral Terrorism}

The ZANU-PF reputation "for spilling blood" 32 grew with the turn of the century. The violence again escalated when the growing opposition

25. Eric Worby, Tyranny, Parody, and Ethnic Polarity: Ritual Engagements with the State in Northwestern Zimbabwe, 24 J. S. AFR. STUD. 561, 565 (1998).

26. Id. at 568-74.

27. Ian Taylor \& Paul Williams, The Limits of Engagement: British Foreign Policy and the Crisis in Zimbabwe, 78 INT'L AFF. 547, 551 (2002).

28. Id.

29. Id.

30. Norma Krieger, Zimbabwe Today: Hope Against Grim Realities, 85 REv. AFR. PoL. ECON. 443, 447 (2000).

31. Id. at $447-48$.

32. Id. at 448 . 
political party-the Movement for Democratic Change (MDC)-won enough seats in the 2000 parliamentary elections to threaten Mugabe's power.

Mugabe and his military cohorts did not take lightly to the threat. Thus, "MDC and suspected sympathizers were potential targets of terror which the ruling party both sanctioned and instigated." 33 A typical example of Zimbabwe's security forces participating in political violence was a joint operation between the military and police in MDC territory: "Ostensibly to restore peace, soldiers and police brought violence to otherwise relatively calm areas by assaulting residents whom they accused of being MDC supporters." ${ }^{34}$

Another instance was when ZANU-PF thugs overran the rural area of Mberengwa district and "mounted a brutally effective crackdown against the MDC." 35 A confiscated farm was transformed into the "lair of a local warlord known as Comrade Biggie Chitoro. From his headquarters, he commanded a small army of 'war veterans' who soon imposed their dominance on Mberengwa's two parliamentary constituencies." ${ }^{36}$ Hundreds were assaulted or tortured, nine women raped, thirty teachers driven from the area, seven schools forcibly closed, and countless villagers forced to flee. ${ }^{37}$

Politically significant victims were taken to Chitoro's lair for torture." "Fainos Zhou, who nominated the MDC candidate for Mberengwa West, was kidnapped and tortured for four days virtually without break, the last three by Chitoro himself. He was bludgeoned with iron bars, and boiling, melting plastic was dripped all over his body." ${ }^{39}$ His wife was gang-raped and sodomized with an iron bar. ${ }^{40}$

These are just a few of the atrocities committed as part of a "comprehensive operation in which squads of mostly uniformed soldiers are deployed in urban townships to drag members of the Movement for Democratic Change (MDC) from their homes and subject them to vicious assault." As one author astutely noted, "[t]his brand of political terror owe[s] its origin to the guerilla war of the 1970s, when Mugabe's army used a combination of intimidation and indoctrination to secure control

33. Id. at 446 .

34. Id. at 450 .

35. David Blair, Degrees in Violence: Robert Mugabe and the Struggle for POWER IN ZIMBABWE 146 (2002).

36. Id.

37. Id.

38. Id. at 148 .

39. Id.

40. Id.

41. Jan Raath, Zimbabwe Army Leads 'Brutal Campaign,' TIMES (London), Mar. 28, 2003 , at 23 . 
over a wide area." ${ }^{, 42}$ It operates on the principle that "[i]f you beat up a teacher in front of a class of 100 , you terrify the children and their 200 parents., 43

This long history of political leaders' subjective control of the military ${ }^{44}$ has "disastrous effects on the coherence, efficiency, and discipline of the army"45 because it undermines both professional military culture and, consequently, civilian control. Unleashing the power of the armed forces to quell political opposition is detrimental not only to civilian control, but, consequently, also to prospects for self rule by law. Zimbabwe therefore makes evident that "[p]oliticizing the military does not engender healthy civil-military relations,"46 and that until the military is brought under civilian control, little hope for democracy and the rule of law remains.

\section{THE JOINT OPERATIONS COMMAND}

Zimbabwe is currently under the de facto control of a group of generals who refer to themselves collectively as the "Joint Operations Command." The generals are a cabal of high-ranking military and security officers, one of which is Mugabe's probable successor. Each member of this unit has played a substantial role in Zimbabwe's history of military violence. Their crimes are of international repute, and each knows that "sealed envelopes in The Hague already await them." ${ }^{47}$ For them, "the only safe way out is to ensure that Mr. Mugabe keeps power." 48

42. BLAIR, supra note 35 , at 149 .

43. Id. at 148 .

44. Michael C. Desch, Threat Environments and Military Missions, in CIVIL-MILITARY RELATIONS AND DEMOCRACY supra note 6, at 12, 14 ("Subjective control refers to the effort to control the military by politicizing it and making it more closely resemble the civilian sector.").

45. Samuel P. Huntington, Reforming Civil-Military Relations, in CrviL-MilutaRY RELATIONS AND DEMOCRACY, supra note 6 , at $3,7$.

46. Desch, supra note 44 , at 26 . Desch also argues that politicizing the military is not "likely to benefit individual civilian factions." Id.

47. Jonathan Clayton, Why the Military Keeps this Ageing Dictator in Power, TMES (London), June 23, 2008, at 7 (internal quotations omitted).

48. Id. 


\section{A. “Coup by Stealth"}

MDC's overwhelming success in the March 29, 2008 elections stunned President Mugabe. ${ }^{49}$ Before the election, several high-ranking members of Mugabe's government issued a joint statement of opposition to MDC, declaring that they would not serve some "puppet."50 Zimbabwe's military leaders had sung this song before when, on the eve of the 2002 elections, they proclaimed that they "would not recognize the presidency of anyone who did not participate in the 1970s war of independence." ${ }^{51}$ Mugabe may have been prepared to step down after his March defeat, but the generals could not let him go. They knew "that Mr. Mugabe's departure would expose them to prosecution," s2 so "they struck a deal guaranteeing his re-election."53

What took place was essentially a "military coup by stealth." 54 The deal was to beat the MDC into submission so to insulate Mugabe's power and, consequently, spare the generals' hides from criminal prosecution. To achieve this end, they waged a campaign "of attacks exceed[ing] anything seen previously during Zimbabwe's long history of electoral violence." ${ }^{55}$ Over a very short period of time, at least eighty-five people were killed, of which at least fifteen were MDC party members, ${ }^{56}$ 1,300 were tortured, and 35,000 left homeless after their homes were burned. ${ }^{57}$ Not only did the generals ignite the fire, but they fueled it as well, arming militias "with weapons such as AK47s, handguns and rifles." 58

\section{B. Partners in Crime}

The generals are "a security politburo made up of military and police generals, senior intelligence officers, prison service officials and

49. Tsvangirai Wins $47 \%$ in Zimbabwe Elections, Say Sources, THE INDEPENDENT (U.K.), Apr. 30, 2008, http://www.independent.co.uk/news/world/africa/tsvangirai-wins-47. in-zimbabwe-election-say-sources-818531.html (Mugabe received 43 percent of the vote).

50. Id.

51. Id.

52. Generals in Charge of Zimbabwe Says Human Rights Report, THE AUSTRALIAN, June 10, 2008, at 1 (Local Section).

53. Id.

54. Id.

55. Id.

56. Ed Harris, Zimbabwe Army 'Gives Weapons to Mugabe Men,' EVENING STD., Apr. 30,2008 , at 27.

57. Clayton, supra note 47.

58. Generals in Charge of Zimbabwe, supra note 52. 
leaders of ZANU.PF." 59 They refer to themselves as the "Joint Operations Command"60 (JOC). Emmerson Mnangagwa, Mugabe's rumored successor, who is said to have a tight grip on the party and the government, leads the JOC. ${ }^{61} \mathrm{He}$ is the current Minister of Housing, and a lawyer by training. ${ }^{62}$ Mnangagwa is known for building the dreaded Central Intelligence Organisation, which he led during the Matabeleland massacres of the $1980 \mathrm{~s}^{63} \mathrm{He}$ also directed Zimbabwe's military intervention into the Democratic Republic of Congo, where he developed a highly profitable venture in illegal arms trades and mineral exports. ${ }^{64}$

The remaining members of the JOC include General Constantine Chiwenga, Commander of the Zimbabwe Defense Force; Augustine Chihure, Commissioner General of the Zimbabwe Republic Police and leader of the Green Bombers paramilitary militia; Retired MajorGeneral Paradzayi Zimondi, Head of the Prisons Service; Air Marshal Perence Shiri, Chief of the Air Force, who controlled the North Koreantrained Fifth Brigade in the Matabeleland massacres and, notably, refers to himself as "Black Jesus"; Brighton Bonyongwe, an intelligence chief feared for his ruthlessness; and, on a more ad hoc basis, Joseph Chinotimba, leader of the War Veterans Association. ${ }^{65}$

The JOC's control over the instruments of political violence protects its members from most, if not all, domestic threats and at the same time obstructs democratic reform in Zimbabwe. Like so many military regimes, the Joint Operations Command will stop at nothing to preserve its power. The members of the JOC remember the Matabeleland massacres and, most importantly, how they succeeded in not only preserving but also expanding their power. But the Movement for Democratic Change has tasted democratic legitimacy, and its members will not go quietly. Thus, the recent acts of political violence--murder, torture, and rape-are likely only the prelude of what is to come.

\section{REALIZING CIVILIAN CONTROL}

As the path to civil-military relations conducive to democracy and the rule of law, Samuel P. Huntington argued for "objective civilian

59. Id.

60. Id. (citing HuMAN RightS WATCH, BULLETS FOR EACH OF YOU: STATE SPONSORED VIOLENCE SINCE ZIMBABWE'S MARCH 29 ELECTION (2008)).

61. Id.

62. Clayton, supra note 47.

63. Id.

64. Id.

65. Id. 
control." ${ }^{\text {"6 }}$ In detailed terms, Huntington once explained that the relationship of objective civilian control requires several conditions:

1) a high level of military professionalism and recognition by military officers of the limits of their professional competence;

2) the effective subordination of the military to the civilian political leaders who make the basic decisions on foreign and military policy;

3) the recognition and acceptance by that leadership of an area of professional competence and autonomy for the military; and

4) as a result, the minimalization of military intervention in politics and of political intervention in the military. ${ }^{67}$

Although Huntington's argument is more than half a century old, it remains the authority on civil-military relations today.

The challenge for Zimbabwe and other countries seeking reform is that objective civilian control depends on legal, political, and institutional assumptions. For example, the "Western ideal of civilian supremacy" ${ }^{68}$ over the military "presupposes decent, law-abiding civilian government." The new MDC majority may be the law-abiding government Zimbabwe needs, but the country remains at least partly, if not primarily, under the control of Mugabe and his armed politburo. In this respect, Huntington's theory provides only an incomplete roadmap to improved civil-military relations.

Huntington's theory, however, and the scholarship that has followed it provide sufficient guidance to set Zimbabwe on the path to objective civilian control and, thus, to set the stage for democratic society ruled by law. This part of the Note thus begins by considering legal controls of Zimbabwe's civil-military relations. Though the existing legal system is not entirely inadequate, this Note proposes constitutional revisions to allocations of power, checks and balances, and limits to military

66. Samuel P. Huntington, The Soldier and the State: The Theory and Politics OF CIVIL-MILITARY RELATIONS 83-85, 94-96 (1957).

67. Huntington, supra note 45 , at 3-4.

68. Charles H. Fairbanks, Jr., The Postcommunist Wars, in CrvIL-MnutaRY RELATIONS AND DEMOCRACY, supra note 6, at 134, 148.

69. Id. 
participation in domestic affairs. Legal reforms alone will not solve Zimbabwe's problems; wide ranging political and institutional reforms will also be necessary.

\section{A. Legal Controls}

The Constitution, the Defence Act, and the National Defence Policy control the Zimbabwean military forces. If Zimbabwe's military leaders were to recognize the law, then the Constitution, Defence Act and National Defence Policy would not be wholly inadequate for the purpose of providing civilian control over Zimbabwe's military. But because Zimbabwe's military has demonstrated that it is "more dangerous to the country than to the enemy," reforms geared towards furthering healthy civil-military relations in Zimbabwe are necessary.

\section{The Constitution}

\section{a. The Executive Branch}

The Constitution of Zimbabwe appoints the President as Commander-in-Chief of the Defence Forces. ${ }^{71}$ The President has the powers "to declare war or make peace"72 and to "determine the operational use of the Defence Forces." ${ }^{73}$ The President appoints the Minister of Defence to oversee day-to-day military operations, ${ }^{74}$ in addition to the members of the Defence Forces Service Commission. ${ }^{75}$ The President also appoints the commanders of the individual military branches, as well as the constitutionally mandated Commander of the Defence Forces. ${ }^{76}$

National defense requires quick, decisive action, and thus the President is best suited to the powers of declaring war and making peace. However, history has shown that in Zimbabwe, the power of the President to "determine the operational use of the Defence Forces" is too easily abused. To limit the scope of this authority, the Constitution should be amended to provide that the Defence Forces shall not act domestically, except to repel a foreign attack or invasion. Moreover, the

\footnotetext{
70. Id. at 149.

71. ZIMBABWE CONST. (2009) ch. IV, pt. 1, art. 27, para. 1.

72. Id. pt. 3 , art. $31 \mathrm{H}$, para. $4(\mathrm{~d})$.

73. Id. ch. X, art. 96 , para. 2 .

74. Chitiyo \& Rupiya, supra note 21.

75. See discussion infra part IV.A.1.c.

76. ZIMBABWE CONST. (2009) ch. X, art. 96, para. 4.
} 
power of the President to appoint a Minister of Defence and military commanders should be limited by the advice and consent of the Parliament, providing an additional legislative check on future executives.

\section{b. The Legislative Branch}

To Parliament the Constitution allocates the authority to provide for the organization, administration and discipline of the armed forces, as well as the appointment and removal of officers. ${ }^{77}$ The Parliament controls the military budget. ${ }^{78}$ The Constitution should be amended to provide that the Parliament have the sole power to appropriate military expenditures, which will further amplify democratic, and thus civilian, control over the military. The power of the purse will also provide the MDC-controlled Parliament a valuable bargaining chip in negotiations to rein in the military. As noted above, the Parliament should also have the power to review the President's appointments to Defence Minister, Defence Forces Service Commission, and military commander, which will help prevent another Mugabe-minded president from stacking the ranks with self-interested tyrants.

\section{c. The Defence Forces Service Commission}

In order to facilitate oversight of the military and to act as liaison between parliament and the military, the Constitution establishes the Defence Forces Service Commission (DFSC) ${ }^{79}$ The DFSC is comprised of the chairman of the Public Service Commission ${ }^{80}$ and not less than two and not more than seven other members appointed by the President. ${ }^{81}$ Members are to be chosen for their ability and experience, professional qualifications, and suitability. ${ }^{82}$ At least one member shall be a person who has held senior rank for at least five years in the Defence Forces. ${ }^{83}$

The DFSC could play an important role in controlling the military. To achieve this end, certain constitutional amendments are needed. ${ }^{84}$

\footnotetext{
77. Id. para. 5

78. Id. ch. XII.

79. Id. ch. X, art. 97.

80. Id. para. 1(a).

81. Id. para. 1(b).

82. Id. para. 2.

83. Id.

84. Diamond \& Plattner, supra note 6, at xxxi (discussing importance of "consolidat[ing] authority over military affairs in a civilian-led and (increasingly) civilianstaffed ministry of defense").
} 
First, the constitutional minimum two members is too inadequate a safeguard against corruption. To help further diversity of opinion and protect against abuse, the DFSC should always be comprised of at least seven members. As previously noted, appointments to the DFSC are limited by the advice and consent of the Parliament. In addition to the Minister of Defence, the Commander of the ZDF should also serve as a member of the DFSC. This will help to facilitate military-civilian relations by providing a constitutionally mandated forum for discourse.

\section{The National Defence Policy}

The National Defence Policy, adopted by Parliament, explicates the principles of what civil-military relations should look like. It provides, among other things, that "the Defence Forces are subordinate to civilian authority" 85 and that "[m]ilitary personnel are prohibited from active participation in politics." ${ }^{86}$ Although the military under Mugabe's rule suggests that military personnel do not recognize or conform to the Defence Policy, its substantive guidelines provide encouraging evidence of at least some commitment to institutional structure and professional culture capable of submitting to civilian authority and refraining from political participation.

\section{B. Political and Institutional Reforms}

The wrangling over Zimbabwe's security forces is at its core a political problem. On the one hand, the MDC presents the possibility of civilian control; on the other, Mugabe and the JOC refuse to relinquish power. Although MDC controls a majority of parliament, legislation is not bulletproof. As long as Mugabe and the JOC control the guns, legal controls have little meaning in Zimbabwe.

Because legal reforms alone will be inadequate to address Zimbabwe's civil-military relations problems, both political and institutional reforms are also necessary. First, Mugabe and his military henchmen must relinquish power, by forcible removal if necessary. Second, and as a result of the transition in political power, steps must be taken to ensure the appeasement of the politically potent war veterans. Furthermore, specific institutional reforms aimed at professionalization, the essence of objective civilian control, must be advanced to reign in military power. Finally, the state police, which played a notable role in recent political violence, must also be reformed

85. Chitiyo \& Rupiya, supra note 21 , at 348 .

86. Id. at 350 . 
towards civilian control.

\section{Disempowering Mugabe and the JOC}

At more than eighty years of age, Mugabe's time in power is necessarily limited, but the same does not hold true for the JOC. Given its control over political violence, the JOC will be difficult to overtake from within. Depending on the facts on the ground, it may be possible to utilize the militias to remove the JOC from power, if Joseph Chinotimba, or someone with similar political clout among the war veterans, is willing. JOC members will not likely agree to exile, for each faces potential indictments in the International Criminal Court. Only if they face criminal prosecution in Zimbabwe will they consider exile and even then it would appear the less favorable alternative. Although their removal probably will not guarantee stability in Zimbabwe, the JOC's continued control will necessarily preclude peace and stability for Zimbabwe, as well as its neighbors, Zambia, Mozambique, Botswana and South Africa.

\section{a. Amnesty}

One possibility for disempowering the JOC is to provide its members with amnesty for their wrongs. However, the JOC leaders will likely see little value, if any, in amnesty. Domestic amnesty will be unappealing because the JOC now enjoys considerable power in Zimbabwe, and the International Criminal Court cannot grant amnesty. Domestic amnesty may be more valuable as a tool for political reconciliation though, if the JOC members were forcibly removed and then indicted for their crimes. Because amnesty in itself is highly unlikely to persuade the JOC to relinquish power, forcible measures are appropriate for consideration.

\section{b. Forcible Removal}

Forcibly removing high-ranking officials in a destabilized state is complicated, but not impossible. The pressing question is which, if any, foreign nation is sufficiently interested in Zimbabwe to aid such an endeavor. Zimbabwe's neighbors, particularly South Africa, have a direct interest in deposing the JOC because its campaigns of political terror send refugees pouring out of Zimbabwe and into South Africa. Similarly, the African Union (AU) has an interest in maintaining the stability of one of its member states, though an already pressing array of problems in other $\mathrm{AU}$ nations might mean the AU can offer little help 
to Zimbabwe.

As the former ruling colonial power, Britain also has an interest in Zimbabwe's crisis. In fact, "[f]ew events in Africa in recent years have so excited British opinion on foreign affairs as the downward spiral of Zimbabwe under President Robert Mugabe." 87 Britain has already enacted strict sanctions against Mugabe and his cohorts, including travel bans and asset freezes. ${ }^{88}$ The European Union has enacted similar restrictions on Mugabe and his men. ${ }^{89}$ Additionally, the recent entry into the conflict of former President Jimmy Carter and former U.N. Secretary General Kofi Annan demonstrates growing international interest in Zimbabwe's state of affairs. ${ }^{90}$

Clandestine removal or assassination is not a realistic option. Perhaps the best that Zimbabwe can hope for is a coup from within the ranks of the military. There is little chance this will happen on its own because the JOC has such a tight grip on power. Thus, aid in cultivating a takeover from within may be the best foreign aid for Zimbabwe's crisis. The conditions may even already be ripe for such a transfer of power given that the youngest member of the JOC is in his 50s. A little encouragement may be all that is necessary to catalyze the coup.

\section{Limiting the Repercussions}

The job does not end with removing the JOC from power because the ensuing power vacuum will be a serious threat to democracy and the rule of law. Under ideal conditions, a coup from within the ranks would provide successors to fill the void. Relative to most African militaries, Zimbabwe's armed forces are generally well-trained, professional, educated soldiers. This is in part due to Zimbabwe's economic troubles of the past decade, which allowed the military to be highly selective in recruiting. ${ }^{91}$ It is thus possible that among the ranks of the officer corps there exists a contingent of established and respected leaders who, because of their age, will not share with the JOC the same beliefs and according loyalty to Mugabe. The prospect of leadership will be an enticing opportunity for many an eager officer. In tandem with recruiting new leadership, civilian leaders should act with haste "to purge potentially disloyal officers and replace them with officers respected by their peers but less associated with the previous military

87. Taylor \& Williams, supra note 27.

88. Id. at 555 .

89. Id.

90. Celia W. Dugger, Over Zimbabwe Objections, Annan and Carter Plan Visit, N.Y. TTMES, Nov. 21, 2008, at A14.

91. Taylor \& Williams, supra note 27. 
regime." 92

\section{a. Professionalize the Forces}

If Zimbabwe's military forces are to protect the people and not plunder them, it will be necessary to "work gradually to restore the prestige of military organizations and the use of force." 93 Years of political abuse have undoubtedly jaded the civilian view of the military in Zimbabwe. To ensure that such abuse ceases and to restore civilian respect of the military, the civilian government must work aggressively to professionalize the security forces. Both resources and training can serve as valuable inroads to the professional culture of an armed force.

Training is a critical component in professionalizing the security forces. Technical and professional training imbues a soldier with the pride of valuable skills. Concurrent reinforcement of institutional functions will help redirect the forces away from political intervention. Furthermore, training can be utilized to affect institutional identity. But, Zimbabwe lacks the capacity to train its forces, thus the question is posed: To whom to look for aid?

Many nations pursue military training aid efforts. Both Britain ${ }^{94}$ and North Korea ${ }^{95}$ trained Zimbabwe's armed forces in the past. The latter should be a last resort, given the political consequences of such an association. Britain, on the other hand, provided military training assistance to Zimbabwe with its British Military Advisory Training Team up until $2001 .^{96}$

The United States also has programs to aid in training Zimbabwe's military, such as the African Crisis Response Initiative or the International Military Education and Training Program (IMET). ${ }^{97}$ At present, these programs "are useful but much too small: Africa's biggest IMET program, in South Africa, amounted to only $\$ 800,000$ last year."98 Perhaps the Obama administration will see that the time may be approaching to increase funding for these programs and "build their capacity for conflict prevention and peace enforcement while helping to ensure that African militaries remain accountable to civilian

92. Diamond \& Plattner, supra note 6, at xxx.

93. Fairbanks, Jr., supra note 68, at 194.

94. Young, supra note 11 , at 134.

95. Worby, supra note 25 .

96. Taylor \& Williams, supra note 27.

97. John Stremlau, Ending Africa's Wars, 79 Foreign AFF., July-Aug. 2000, at 117, 125.

98. Id. 
authorities." 99

While training may be a good in itself for the Zimbabwean military, training in the context of an ongoing mission would be far more facilitative of civilian control. Soldiers will be able to immediately apply new information and reinforce the pride of development. It will also buttress authority and the civilian controls responsible for implementing the training regimens. Furthermore, aid from prominent military powers may help to improve public perception of military professionalism. Wherever Zimbabwe's military may be deployed, training should be tailored to that mission.

Training, however, is only one way to professionalize the forces. Of additional importance to professionalization efforts is military equipment. "Most African state armies are in decline, beset by a combination of shrinking budgets, international pressures to downsize and demobilize, and the lack of freely accessible military assistance that characterized the cold war period." 100 And Zimbabwe is no exception to this rule. A "report on Zimbabwe's army-long thought to be one of the most competent militaries on the continent-found that the force had only $5 \%$ of its vehicles in working order, monthly pilot training had been abandoned, and $70 \%$ of the troops in one brigade had been off duty for a year or more, on forced leaves to save money." 101 Over the ten-year period from 1987 to 1997, the ZNA forces saw an eleven percent reduction in soldiers per 1,000 citizens. ${ }^{102}$

But in the last several years, Zimbabwe has invested significantly in its forces, with military expenditures increasing by approximately seven hundred percent from 2000 to $2002 .{ }^{103}$ China, which has focused many diplomatic efforts on Africa, is Zimbabwe's primary source for arms and a major trade ally. ${ }^{104}$ In 2004 , Zimbabwe ordered more than $\$ 240$ million in military equipment from China, including twelve fighter jets and one hundred military vehicles. ${ }^{105}$ Two years later, Zimbabwe bought six

99. Id.

100. Jeffrey Herbst, African Militaries \& Rebellion: The Political Economy of Threat and Combat Effectiveness, 41 J. PEACE RES. 357, 359 (2004) (citing William G. Thom, Judging Africa's Military Capabilities, 5 J. 3D WORLD STUD. at 52, 52-65 (1995)).

101. Id. (citing Zimbabwe: Report Cites UK Paper on "Ominous" State of Defence Force, HARARE ZIMBABWE STD., May 11, 1998 (reproduced in FOR. BROAD. INFO. SvC., May 12, 1998)).

102. Id.

103. Chitiyo \& Rupiya, supra note 21 , at 353 . This spending increase was likely the product of escalating political violence.

104. Zimbabwe Arms Ship Heads Back to China, Toronto STAR, Apr. 25, 2008, at AA01.

105. Tom Carter, Zimbabwe Stocks Up on Jets, Arms, WASH. TIMES, June 15, 2004, at A1. 
more jets from China, as well as additional weaponry from North Korea. ${ }^{106}$ However, amid reports of political violence, China recently ordered a ship to return to China without delivering its arms payload to the Mugabe government. ${ }^{107}$

While these weapons can be used to further destabilize Zimbabwe, in the right hands they can serve more legitimate purposes. Equipment is the pride of a military. There is little an armed force enjoys more than putting its technological toys to use. In the context of domestic political turmoil, such enjoyment has led to atrocity. But in the right environment, the military can employ its new equipment to serve its true purpose of defending civilians from armed conflict.

\section{b. Send the Troops on a Mission}

A "state whose military has a clear, traditional, external mission is likely to have good civil-military relations (defined in terms of the civilian leadership's being able to impose its will upon the military)." 108 This is in contrast to domestic military involvement, which "erodes the boundaries of the military's distinct professional role as a combat force, and immerses the armed forces in a myriad of domestic political issues and conflicts." 109 In Zimbabwe's case, an external mission would be extremely valuable to establishing good civil-military relations. It will help to reinforce training in the context of real-world professional objectives, while also reducing participation in domestic politics.

In light of the declining existence of external threat, peacekeeping missions play an increasing role in military activity. ${ }^{110}$ In the recent past, Zimbabwe's armed forces participated in external missions in Mozambique, Somalia, Angola, and the Democratic Republic of Congo. ${ }^{11}$ The three former interventions were under U.N. auspices, and the forces operated with relative responsibility. Mugabe chose to intervene in the DRC after its president, Laurent-Désiré Kabila, begged for Zimbabwe's aid in a flaring civil war. ${ }^{12}$

The acts of the Zimbabwean military in the DRC were often questionable, and sometimes criminal. The army became "a formal

106. Gavin du Venage, Zimbabwe Buys Jets from China, The Australian, Aug. 29, 2006, at 10 .

107. Zimbabwe Arms Ship Heads Back to China, supra note 104.

108. Desch, supra note 44 , at 25.

109. Diamond \& Plattner, supra note 6 , at xxxi.

110. Huntington, supra note 45 , at 10.

111. Young, supra note 7 , at 247.

112. Wolf-Christian Paes \& Timothy M. Shaw, Praetorians or Profiteers? The Role of Entrepreneurial Armed Forces in Congo-Kinshasa, in THE MILITARY AS AN ECONOMIC ACTOR 143, 166-67 (Jörn Brömmelhörster \& Wolf-Christian Paes eds., 2003). 
stakeholder in economic enterprises," such as Oryx Diamonds, a joint venture between the Congolese and the Zimbabwean armed forces. ${ }^{113}$ However, these transgressions were largely attributable to military leadership. Although the DRC contracted the Zimbabwe Defense Industries to provide food, uniforms and weaponry to the Congolese armed forces, ${ }^{114}$ Mugabe declared the mission to be "a self-financing intervention." 115 Mugabe used "business deals and mining contracts in the Democratic Republic of Congo to keep senior officers in the Zimbabwe armed forces on his side," forces to pursue "military business."

Given its past transgressions, Zimbabwe's army still remains "undoubtedly one of the most professional, competent, and experienced militaries in sub-Saharan Africa." 118 Committing troops to an external mission will remove potential actors of political violence from a tenuous domestic situation. As a proactive step toward its own security and the security of others, an external troop commitment might also act as a sign of international goodwill, improving the odds of international aid to Zimbabwe's internal struggles. The probability of bringing this favor can be increased if civilian leaders remind the public of the importance of a professional military's role. ${ }^{119}$

One possible external mission would be Zimbabwe's commitment of troops to the African Union-United Nations Hybrid Operation in Darfur (UNAMID). As of recent, the mission in Darfur included, among others, units from Bangladesh, China, Egypt, Ethiopia, Gambia, Kenya, Nigeria, Rwanda, Senegal, and South Africa. The participation of China is significant because, as Zimbabwe's primary source of arms, China may be able to leverage Zimbabwe's participation as a condition for trade.

UNAMID is desperately in need of manpower. While its mandate calls for 20,000 troops, more than 6,000 police, and a large civilian component, ${ }^{120}$ "[t]hroughout 2008 , UNAMID continued to face shortfalls

113. Id. at 167 .

114. Id. at 166 .

115. Id. at 167 .

116. Robert Luckham, Military Withdrawal from Politics in Africa Revisited, in THE Military and Politics IN AFrica: From Engagement to Democratic and Constitutional Control 91, 102 (George Klay Kieh, Jr. \& Pita Ogaba Agbese eds., 2004).

117. Paes \& Shaw, supra note 112 , at 167.

118. Young, supra note 7 , at 247.

119. Desch, supra note 44, at 27.

120. UNAMID, Background Information, http://www.un.org/Depts/dpko/missions/ unamid/background.shtml (last visited Mar. 14, 2010). 
in troops and critical transport and aviation assets." 21 Only half of the troops and less than one third of the police mandates have been met. ${ }^{122}$ Zimbabwe has more troops than it can domestically tolerate, and sending a large contingent of those troops to Darfur will help the civilian government gain control. Additionally, Zimbabwe possesses the critical transport and aviation assets UNAMID so desperately needs. ${ }^{123}$

Zimbabwe's role in Darfur is already clearly defined as a peacekeeping mission. ${ }^{124}$ UNAMID will thus provide Zimbabwe's armed forces with much needed professional experience. UNAMID may also provide opportunities for some of Zimbabwe's many unemployed but qualified civilians, helping to bring the mission into favor with the civilian population.

The possibility of access to a pool of monetary resources is also a compelling reason for Zimbabwe to deploy troops under the UNAMID mandate. With a budget of $\$ 1.7$ billion for fiscal year 2008-2009, UNAMID is the largest U.N. peacekeeping operation. ${ }^{125}$ Such resources will provide a legitimate, reliable source of sustenance to wean Zimbabwe's ranks from their entrepreneurial pursuits. It will also help to command and control the troops. Moreover, respectable employment will create endearment for those directing the professional mission, thus reinforcing the authority of the new military leadership under the control of civilian government.

\section{c. Appease the Veterans}

War veterans permeate Zimbabwe's civil society. Many ex-fighters were absorbed into the national police force. ${ }^{126}$ Many others were deployed in Operation Soldiers Employed in Economic Development, a mostly failed attempt to demobilize war veterans. ${ }^{127}$ But the war vets are organized and they enjoy the support of Zimbabwe's two most powerful institutions, the army and police. ${ }^{128}$ In 1997, "[v]eterans in the civilian sector took to the streets to demand war pensions and other social benefits and on a number of occasions held senior party and

121. Id.

122. Id.; see also UNAMID, Facts, http://www.un.org/en/peacekeeping/missions/ unamid/facts.shtml (last visited Mar. 14, 2010).

123. Carter, supra note 105.

124. UNAMID, Mandate, http://www.un.org/Depts/dpko/missions/unamid/mandate. html (last visited Jan. 23, 2010

125. Id.

126. Alice Hills, Towards a Critique of Policing and National Development in Africa, 34 J. MOD. AFR. STUD. 271, 284 (1996).

127. Chitiyo \& Rupiya, supra note 21 , at 345.

128. Krieger, supra note 30 , at 443-44. 
government officials hostage." ${ }^{129}$ The police "stood by . . . and Mugabe agreed to pay [the veterans] gratuities and pensions."130

The fact that the war veterans are not Mugabe's pawns, but rather are organized around their own interests, is encouraging for it suggests that removing Mugabe and the JOC will not necessarily lead the veterans to further violence. In reality, the motivation for the veterans' contributions to the current chaos is at least twofold. On the one hand, there is an obvious historical connection between Mugabe and the vets, as he led them in the war for independence. Thus the veterans may be motivated to protect their leader. On the other hand are the grim realities of life on the ground in Zimbabwe. In such conditions of strife, it may be that the veterans are motivated less out of loyalty to Mugabe and more out of frustration with living in dire straits. To this extent, the war veterans may be appeased with statutory concessions, as they were in 1997.

A variety of conciliatory options exist, for example insurance, periodic payments, or land grants, all of which can be enacted through statutory provisions. With catastrophic inflation driving the value of the Zimbabwean dollar to be less than value of the ink and paper used to make it, the effectiveness of concessions may be limited. ${ }^{131}$ Given the consequences of the last attempt at land reform, a new government would rightly be hesitant to reengage that subject. Nevertheless, Mugabe's closest allies benefited most from the land reforms, taking on large holdings of land. Thus the disenfranchisement of Mugabe and the JOC may leave the government with large quantities of land at its disposal. Such swaths could be divided up among the veterans, or instead put to use with the proceeds going to the benefit of veterans.

In any case, the veterans have contributed substantially to the current crisis, and they are too many to deal with on individual bases. Bringing the veterans within the framework of objective civilian control will likely require "processes of bargaining, dialogue, cooperation, and consensus-building."

\section{The Police}

Distinguishing the police functions from military objectives will also be critical to Zimbabwe's survival. To a lesser extent than the military, the police forces have also been used as tools of political violence. To

129. Id.

130. Id. at 444.

131. A recent search revealed that an uncirculated $\mathrm{Z} \$ 1$ billion note can be purchased on ebay (B) for less than US $\$ 5$.

132. Diamond \& Plattner, supra note 6 , at $\mathrm{xxx}$. 
prevent future abuses, many of the principles for controlling the military can also be applied to the police. And with the military refocused on an external mission in Sudan or elsewhere, and consequently a more stable domestic situation, the government can focus on professionalizing the police force.

First, the police, like the military, need a clearly defined mission. A political campaign against some moral evil, such as drugs, can focus the police in a way that can both serve the public good and reinforce the legitimacy of civilian government. Although it might risk efforts to distinguish the police from the military, some of Zimbabwe's police could be deployed under UNAMID auspices as well. Second, training can help to clarify the responsibilities and prerogatives of the police force and to reinforce professional pride. Finally, the civilian government must take care of the police, just as it must the military. Reliable pay, fair treatment, and clear, objective guidance will help provide more stable police-citizen relations.

\section{CONCLUSION}

Zimbabwe's history of military participation in domestic politics has reinforced the view of "the armed forces that their involvement in broad economic, political and social problems is legitimate."133 Zimbabwe's democratic survival depends on rebutting this message, but the old guard of the Mugabe regime stands in the way. Their removal will be challenging, but not impossible. With careful consideration of candidates to replace military leadership, compromising negotiations to win the support of the war veterans, and carefully crafted legal and political reforms, Zimbabwe can open the door to democracy and the rule of law.

The multidisciplinary nature of the reforms suggested demonstrates the complexity of reforming civil-military relations in pursuit of objective civilian control. That reforms can lead to improved military relations proves the possibility of realizing critical preconditions to democracy and rule of law. Crafting and implementing reforms in other nations suffering from military oppression is of critical importance to the spread of democracy and the rule of law, and this analysis demonstrates that reform is plausible. Stable relations do not happen overnight, especially in a nation as destitute as Zimbabwe, but with incremental progress will come tremendous benefits. "As democratic institutions sink firm roots and popular commitment to the constitutional system deepens, the scope for the military to intervene in

133. Id. at $\mathrm{xxxi}$. 
politics, or even to rattle its sabers menacingly, diminishes."134

134. Id. at xxxiii. 
